\title{
Juvenile Huntington disease in Argentina
}

\author{
Doença de Huntington juvenil na Argentina \\ Emilia Mabel Gatto ${ }^{1,2}$, Virginia Parisi², José Luis Etcheverry', Ana Sanguinetti', Lorena Cordi³, AdrianBinelli \\ Gabriel Persi², Ferdinando Squitieri ${ }^{4}$
}

\begin{abstract}
We analyzed demographic, clinical and genetic characteristics of juvenile Huntington disease (JHD) and it frequency in an Argentinean cohort. Age at onset was defined as the age at which behavioral, cognitive, psychiatric or motor abnormalities suggestive of JHD were first reported. Clinical and genetic data were similar to other international series, however, in this context we identified the highest JHD frequency reported so far $(19.72 \% ; 14 / 71)$. Age at onset of JHD is challenging and still under discussion. Our findings reinforce the hypothesis that clinical manifestations, other than the typical movement disorder, may anticipate age at onset of even many years. Analyses of JHD cohorts are required to explore it frequency in populations with different backgrounds to avoid an underestimation of this rare phenotype. Moreover, data from selected populations may open new pathways in therapeutic approaches and may explain new potential correlations between HD presentations and environmental or biological factors.
\end{abstract}

Keywords: juvenile Huntington disease, chorea, genetics, Huntington disease prevalence.

\begin{abstract}
RESUMO
Foram analisadas as características demográficas, clínicas e genéticas de doença de Huntington juvenil (JHD) e na freqüência em uma coorte argentino. A idade de início foi definida como a idade em que distúrbios comportamentais, cognitivos, psiquiátricos ou anormalidades motoras sugestivas de JHD foram relatada pela primeira vez. Os dados clínicos e genéticos foram semelhantes aos de outras séries internacionais, no entanto, neste contexto identificamos a maior freqüência de JHD relatados até agora (19,72\%; 14/71). A idade de início de JHD é um desafio ainda em discussão. Nossos resultados reforçam a hipótese de que as manifestações clínicas, além do transtorno de movimento típico, pode antecipar a idade de início em muitos anos. As análises de coortes de JHD são obrigados a explorar frequências em populações com diferentes formações, para evitar uma subestimação deste fenótipo raro. Além disso, os dados de populações selecionadas podem abrir novos caminhos em abordagens terapêuticas e pode explicar novas correlações potenciais entre apresentações de HD e fatores ambientais ou biológicas
\end{abstract}

Palavras-chave: doença de Huntington juvenil, coreia, genética, doença de Huntington predomínio.

Huntington disease (HD) is an autosomal dominant and rare neurodegenerative disorder characterized by motor, cognitive and behavioral features caused by a CAG expansion in the HTT gene beyond 35 repeats $^{1,2}$. Although HD typically manifests in adulthood, the juvenile form (JHD) may begin before the age of 20 years $^{2}$. Classically, JHD descriptions report an association with expanded alleles as large as 60 or more CAG repeats. Nevertheless, JHD mutation size may, although rarely, fall within the expanded repeat range typical of adult cases ${ }^{3}$. It is widely accepted that JHD is rarer than adulthood HD, showing an average prevalence rate of approximately $5 \%^{4,5,6,7,8,9,10}$ (i.e. ranging from $1 \%$ to $15 \%$ of all HD cases), with a mean prevalence of childhood (0-10 years) and adolescent (11-20 years) onset of $1.3 \%$ and $4.4 \%$ of all cases, respectively ${ }^{2,5,6,7}$.

The clinical presentation of JHD is generally different from adult HD and is, in most cases, characterized by features of parkinsonism; for example, in the so-called Westphal rigid variant there is remarkable bradykinesia, rigidity and dystonia, as well as nonspecific behavioral disturbances, learning difficulties, severe cognitive impairment and neuropsychiatric manifestations. In addition, childhood patients may also present with cerebellar features (i.e. tremor, postural instability, disdiadocokinesia, limb incoordination, cerebellar atrophy), epilepsy, myoclonus, spasticity, developmental delay and autism $2,5,6,8,9,10,11,12,13$. The variable and nonspecific

\footnotetext{
${ }^{1}$ Instituto Neurociencias de Buenos Aires (INEBA), Departamento de Movimientos Anormales, Buenos Aires, Argentina;

2 Sanatorio de la Trinidad Mitre, Departamento de Neurología, Buenos Aires, Argentina;

${ }^{3}$ Hospital Pedro de Elizalde, Departamento de Neuropediatría, Buenos Aires, Argentina;

${ }^{4}$ San Giovanni Rotondo and Mendel Institute of Human Genetics, IRCCS Casa Sollievo della Sofferenza, Rome, Italy.
}

Correspondence: Emilia Mabel Gatto; Juramento $11553^{\circ} \mathrm{A}$ (Zip code: 1428) Buenos Aires, Argentina ; E-mail: emiliagatto@fibertel.com.ar 
clinical picture overlapping other early-onset neurological disorders may represent a critical diagnostic challenge ${ }^{6,14}$.

Considering the obvious ethical restriction in testing minors ${ }^{15,16}$, a rather limited number of studies have so far reported detailed clinical features of JHD $2,5,7,10,17$. However, epidemiological, demographic and clinical genetic studies of JHD in populations with different ethnic backgrounds may contribute to better understand the variability in the phenotype and frequency $y^{5,9,13,18}$.

Therefore, we conducted an observational study to describe clinical, epidemiological, demographic and genetic characteristics of a series of JHD patients followed up by a single center in Argentina and compared our findings with those reported in different populations around the world.

\section{METHOD}

We retrospectively identified all subjects with a diagnosis of JHD, as reported in our database between June 2003 and March 2013. The study was approved by the Institutional Review Board of our Institute.

\section{Diagnosis of HD}

The diagnosis was established by the evidence of a patient's positive family history with at least one first degree relative positive to the genetic test for HD, plus motor, cognitive or psychiatric signs or symptoms suggestive of HD and by the confirmation of a positive genetic test.

"Suggestive symptoms of HD" included movement disorders (i.e. chorea, parkinsonism, dystonia), behavioural changes (i.e. depression, apathy, anxiety, irritability and aggresion) and cognitive manifestations (i.e. learning difficulties at school and/or cognitive decline).

\section{Age at onset}

The most frequently used criteria for diagnosis of HD is "score4", refered as "unequivocal signs" of HD according to the "Diagnostic Confidence Level" (DCL) of the Unified Huntington Disease Rating Scale (UHDRS). However, in the last years, large observational studies (PREDICT-HD and Track-HD) suggest that disease onset is a process that occurs gradually over years or even decades before clear motor manifestations ${ }^{1,19,20}$. These criteria should be, very likely, taken in account in future ${ }^{21}$. If we take in account these new observations, we may define age at onset in our cohort as the age at which severe behavioral, cognitive or motor abnormalities suggestive of JHD were notified by a careful interview of relatives and caregivers by a specialist with expertise in $\mathrm{HD}^{2}$. Inclusion criteria were: (1) age at onset $\leq 20$ years; and (2) diagnosis of JHD, as defined above. For all subjects who met the inclusion criteria, an informed consent was obtained from the patient and one parent or legal representative, as appropriate. The medical files of all these patients were reviewed to collect demographic, clinical and genetic data. Patients were classified into childhood ( $\leq 10$ years old) and adolescent-onset ( $>10$ years old) subgroups in order to highlight differences. For comparison between continuous variables, Wilcoxon test was used. Correlation was calculated by Pearson-Chi-square correlation test and Rho Spearman, as appropriate. Statistical analysis was conducted using G-Stat 2.0. A $\mathrm{p} \leq 0.05$ was considered statistically significant.

\section{RESULTS}

Clinical, demographic and genetic data, including symptoms at onset and age of further main motor manifestations, are listed in Tables 1 and 2. From a cohort of 71 HD cases that compose our Institutional HD data base, 10 unrelated and 4 related HD patients ( 6 males and 8 females, from 12 unrelated families) fulfilled the proposed JHD criteria (19.72\%). All but 2 patients were heterozigous for CAG expanded mutation in $H T T$ gene. Mean age at onset was $12.64 \pm 5.27$ years (range 4-20 years). When we restricted our JHD classification exclusively to those patients with unequivocal neurological motor onset symptoms ("score 4" of DCL), only 4 patients (cases $\# 3,6,7,8$ ) respected the motor criteria, with an estimated prevalence of $5.73 \%$ of all HD cases. Moreover if we included patients with seizures or declining school performance plus cognitive decline, two additional classically accepted manifestations of JHD, (cases \# 9 and 11), the prevalence increase to $8.41 \%$ (Table 2).

Family history of HD was positive at the time of onset symptoms for all patients but one. In this case, the patient was adopted and no information about his biological parents was available. Six patients showed a childhood-onset ( $\leq 10$ years; $42.86 \%$ of the JHD; $8.45 \%$ of the whole HD cohort), with a mean age at onset of $7.50 \pm 2.51$ years (range 4-10 years). Eight patients had an adolescent-onset ( $>10$ years; $57.14 \%$ of the JHD; $11.26 \%$ of the whole HD cohort), with a mean age at onset of $16.50 \pm 2.72$ years (range 13-20 years). All patients in the childhood-onset group and $4 / 7$ cases $(57.14 \%)$ in the adolescent-onset group had a paternal inheritance. The mean CAG repeat number was $53 \pm 12.45$ (range 40-80). The mean number of expanded CAG repeats in patients with infantile onset ( $\leq 10$ years) was larger, although not statistically significant, than those with age at onset $>10$ years $(56.25 \pm 16.28$ vs. $51.38 \pm 11.01 ; \mathrm{p}=\mathrm{NS})$. Four JHD individuals had $\geq 60 \mathrm{CAG}$ repeats ( $28.57 \%$ of JHD; $5.63 \%$ of all HD cases), and only one of them had a childhood-onset at theage of 4 years with 80 CAG repeats. The regression analysis between length of the CAG repeat and age at onset failed to reach statistical significance (Rho Spearman -0.27; $\mathrm{p}=0.38$ ). In two siblings of this JHD cohort, a molecular confirmation of HD was not available. However, the expanded 48 
Table 1. Demographic, clinical and genetic data from juvenile Huntington disease cohort.

\begin{tabular}{|c|c|c|c|c|c|c|c|c|c|}
\hline \multirow{2}{*}{$\begin{array}{l}\text { Patient } \\
\text { No. }\end{array}$} & \multirow{2}{*}{$\begin{array}{c}\text { Age at } \\
\text { onset } \\
\text { (years) }\end{array}$} & \multirow[b]{2}{*}{ Gender } & \multicolumn{2}{|c|}{ Onset manifestations } & \multirow{2}{*}{$\begin{array}{c}\text { Age at } \\
\text { diagnosis } \\
\text { (years) }\end{array}$} & \multicolumn{2}{|c|}{ CAG $(n)$ repeats } & \multirow[b]{2}{*}{ Inheritance } & \multirow{2}{*}{$\begin{array}{c}\text { Age at } \\
\text { genetic test } \\
\text { (years) }\end{array}$} \\
\hline & & & Non-motor symptoms & $\begin{array}{c}\text { Motor } \\
\text { symptoms }\end{array}$ & & Expanded & Unexpanded & & \\
\hline 1 & 20 & $M$ & Depression, alcoholism & -- & 21 & 51 & NA & Maternal & \\
\hline 2 & 17 & M & Irritability & -- & 38 & 44 & 18 & Maternal & 41 \\
\hline 3 & 4 & $\mathrm{~F}$ & $\begin{array}{c}\text { Depression, phobia, autism, } \\
\text { seizures }\end{array}$ & -- & 15 & 80 & 22 & Paternal & \\
\hline 4 & 13 & M & Behavioral changes & -- & NA & 40 & 20 & Paternal & \\
\hline 5 & 19 & $\mathrm{~F}$ & $\begin{array}{c}\text { Obsessive-compulsive behavior, } \\
\text { explosive }\end{array}$ & -- & 24 & 41 & 18 & Maternal & 24 \\
\hline 6 & 16 & $\mathrm{~F}$ & $\begin{array}{l}\text { Wayward, obsessive, tics, } \\
\text { aggressive }\end{array}$ & -- & 16 & 66 & 19 & Paternal & \\
\hline 7 & 10 & $\mathrm{~F}$ & -- & Parkinsonism & 11 & NA & NA & Paternal & \\
\hline 8 & 8 & $\mathrm{~F}$ & -- & Parkinsonsim & 9 & NA & NA & Paternal & \\
\hline 9 & 5 & $\mathrm{~F}$ & $\begin{array}{c}\text { Cognitive decline, behavioral, } \\
\text { disorders }\end{array}$ & -- & 25 & 43 & 24 & Paternal & 26 \\
\hline 10 & 15 & M & $\begin{array}{l}\text { Illicit-drug use (cocaine), } \\
\text { tobacco. }\end{array}$ & -- & 27 & 64 & 13 & Unknown & \\
\hline 11 & 13 & M & Declining school performance & -- & 27 & 62 & 19 & Paternal & \\
\hline 12 & 19 & $\mathrm{~F}$ & Behavioral disorders. Irritability, & -- & 30 & 43 & 26 & Paternal & 30 \\
\hline 13 & 8 & $\mathrm{~F}$ & Irritability, depression & -- & 28 & 51 & 22 & Paternal & 30 \\
\hline 14 & 10 & M & -- & Tics & 36 & 51 & 19 & Paternal & 36 \\
\hline
\end{tabular}

NA: not available. --: none.

Table 2. Clinical evolution and progression.

\begin{tabular}{|c|c|c|}
\hline Patient No. & Further motor and non motor manifestations (Age in years) & Evolution \\
\hline 1 & Tics (23), falls (24), facial dystonia (25), pendular reflex (25), chorea (26), insommia (26), apathy (26) & -- \\
\hline 2 & Chorea (34), falls (35), tremor, postural instability (38), dysphagia, dementia (39), wheel-chair (39) & Institutionalized (39) \\
\hline 3 & Dysarthria, dysphagia, severe dystonia, parkinsonism, spasticity, wasting. & Death (16) \\
\hline 4 & NA & -- \\
\hline 5 & NA & -- \\
\hline 6 & Parkinsonism, rigidity, dystonia, dementia, dysphagia (20) & -- \\
\hline 7 & Severe dystonia, parkinsonism, dementia, dysphagia, dysarthria (18) & -- \\
\hline 8 & Severe dystonia, parkinsonism, dementia, dysphagia, dysarthria (16) & -- \\
\hline 9 & Declining school performance, special school (6), suicidal attempt (25), tics (25), chorea (27) & -- \\
\hline 10 & Chorea (27) & Death (27) \\
\hline 11 & Chorea (27) & -- \\
\hline 12 & Facial tics (19), chorea (30) & -- \\
\hline 13 & Postural instability, falls (27) & -- \\
\hline 14 & Parkinsonism (35) & -- \\
\hline
\end{tabular}

NA: not available.

CAG mutation detected in their father, as well as a significant decline in their learning performance at school, associated with progressive parkinsonism (i.e. severe extrapyramidal rigidity in upper and lower limbs and severe bradykinesia) and with severe caudate and putaminal atrophy, are strongly suggestive of Westphal rigid variant of HD in these patients. Mean time from symptom onset to medical diagnosis in our cohort was $10.86 \pm 8.90$ years (range 0-26). The most prevalent onset symptoms were behavioral and cognitive impairment (11/14; 78.57\%); motor onset symptoms, other than chorea, were identified in 3 patients. Childhood-onset patients manifested behavioral, cognitive and psychiatric symptoms at the beginning of the disease in 3 out of 6 cases, parkinsonism in 2 out of 6 cases, tics in 1 out of 6 cases, and seizures in only one case. By retrospective analysis, we found that 12 out of 14 cases showed motor manifestations during their life and in three cases only the symptom "chorea" contributed to the phenotype (Table 2).

\section{DISCUSSION}

We report the first clinical, demographic and genetic analysis of a selected JHD population coming from several regions of Argentina to our centre in Buenos Aires. In our study, the overall estimated JHD prevalence is higher than any other population with different ethnic background (2.4-16\%) $)^{3,5,7,22}$. 
However, caution should be exercised with the inclusion criteria we used to determine the age at onset ${ }^{5,7,20}$. At present, we are lacking a specific standardized scale to score motor and functional impairment in young people with $\mathrm{HD}$; the European HD Network is actively working to validate this ${ }^{2}$. Until then, we cannot systematically score HD progression rate in young people, and the description remains qualitative, as we have reported in Tables 1 and 2. Classically, age at onset was established on the basis of 'score equal to 4', according to the DCL of the United Huntington's Disease Rating Scale (UHDRS) in a mutation carrier subject ${ }^{19}$. Nevertheless, several reports on pre-manifest subjects remarked the occurrence of non-motor behavioral and cognitive manifestations anticipating the typical motor signs and symptoms by even many years ${ }^{19,20,21,22,23}$, thus making the definition of age at onset in JHD still controversial $^{5,6,19,20,21,22,23}$. Recently, Reilmann et al., suggested to take in account the whole individual medical history, i.e. including cognitive, behavioural and functional assessments, as well as new clinical quantitative motor approaches (i.e. Q-Motor assay), to ascertain HD clinical diagnosis and disease onset. The DCL Score $=4$ will, therefore, very likely be replaced in the near future by much more exhaustive strategic assessments ${ }^{21}$.

A recent analysis of children, who were predicted to manifest HD even decades later during their lives, highlighted behavioral and morphometric abnormalities in spite of the absence of neurological manifestations ${ }^{24,25}$. Such evidence supports the need for new, broader clinical diagnostic criteria for JHD cases ${ }^{19}$ and which are not exclusively based on motor manifestations. Moreover, cognitive decline appears as the most common clinical onset manifestation in $\mathrm{JHD}^{5,19,26}$.

However, if we determine the age at onset by considering the first motor manifestations only, as is generally accepted for adulthood HD, our JHD prevalence drops from $19.72 \%$ to $5.73 \%$, thus overlapping the mean ranges reported by others ${ }^{3,5,7,17,22}$. We therefore believe that JHD prevalence variability depends on the different clinical criteria to define age at onset ${ }^{19}$ and would urgently require further clinical studies on larger JHD cohorts to correctly interpret HD onset. The most recent findings from the TRACK-HD study, which sought to identify predictors of phenotypic progression and disease onset in premanifest and early-stage $\mathrm{HD}$, may contribute to support this hypothesis ${ }^{1}$.
Our data on the non significant inverse correlation between the length of the CAG repeat and the age at onset in individuals with paternal inheritance, is congruent with reports from others ${ }^{2,3,6,7,27}$ and reinforces the hypothesis that factors other than the expanded mutation size contribute to the disease onset and development. JHD is usually associated with a CAG repeat of $>60$ in approximately $50 \%$ of cases, while childhood onset often exhibits a CAG repeat size of $>80^{3}$. However, consistent with findings in adult cases, CAG repeat size does not always correlate with JHD age at onset ${ }^{3,4,5,6,18}$, mainly in the case of infantile onset ${ }^{3}$. On the other hand, the mean time from onset symptoms to diagnosis was longer than previously observed (10.86 \pm 8.90 years vs. 4.7 years) ${ }^{4}$. Probably, the heterogeneity phenotype, irrespective of the childhood or adolescent-onset (i.e. decline in school performance, seizures, parkinsonism, tics, irritability, clumsiness, etc.), may also contribute to a delayed diagnosis. However, we cannot exclude a recall bias.

Possible limitations of our study include the potential for inaccurate data due to the retrospective analysis of cases, recall bias and the obvious difficulty in interpreting age at onset compared to age at diagnosis, the lack of specific standardized evaluation scales, and the small size of the sample. Nevertheless, we believe that this series may contribute to the expansion of knowledge of the JHD variant, which is already rare and, particularly so, due to the limited number of reports focusing on this topic from South America, with the exception of the Venezuelan community ${ }^{23}$.

In conclusion, the analysis of our JHD cohort illustrates that early symptoms may be present long before the classical diagnostic criteria are fulfilled. A new definition for JHD age at onset is therefore requiredand expected.

\section{Acknowledgements}

The authors wish to thank Martín Grecco MD, for his review of the manuscript. The authors wish to thank patients and their families for participating in this study. Ferdinando Squitieri is Founder and Director of LIRH Foundation (Lega Italiana Ricerca Huntington e malattie correlate onlus - www.lirh.it).

\section{References}

1. Tabrizi SJ, Scahill RI, Owen G, Durr A, Leavitt BR, Roos RA et al. TRACK-HD Investigators. Predictors of phenotypic progression and disease onset in premanifest and early-stage Huntington's disease in the TRACKHD study: analysis of 36-month observational data. Lancet Neurol. 2013;12(7):637-49. doi:10.1016/S1474-4422(13)70088-7

2. Quarrell OWJ, Brewer HM, Squitieri F, Barker R, Nance MA, Lanswehrmeyer BG. "Juvenile Huntington's Disease (and other trinucleotide repeat disorders)". Oxford: Oxford University Press; 2009.

3. Squitieri F, Frati L, CiarmielloA, Lastoria S, Quarrell O. Juvenile Huntington's disease: does a dosage-effect pathogenic mechanism differ from the classical adult disease? Mech Ageing Dev. 2006;127(2):208-12. doi:10.1016/j.mad.2005.09.012

4. Douglas I, Evans S, Rawlins MD, Smeeth L, Tabrizi SJ, Wexler NS. Juvenile Huntington's disease: a population-based study using the General Practice Research Database. BMJ Open. 2013;3(4). pii:e002085. doi:10.1136/bmjopen-2012-002085

5. Quarrell O, O'Donovan KL, Bandmann O, Strong M. The prevalence of Juvenile Huntington's disease: a review of the literature and meta-analysis. PLoS Curr. 2012;4:e4f8606b742ef3. doi:10.1371/4f8606b742ef3 
6. Koutsis G, BChir MB, Karadima G, Kladi A, Panas M. The challenge of juvenile Huntington disease: To test or not to test. Neurology. 2013;80(11):990-6. doi:10.1212/WNL.0b013e31828727fa

7. Cannella M, Gellera C, Maglione V, Giallonardo P, Cislaghi G, Muglia $\mathrm{M}$ et al. The gender effect in juvenile Huntington disease patients of Italian origin. Am J Med Genet B Neuropsychiatr Genet. 2004;125B(1):92-8. doi:10.1002/ajmg.b.20110

8. Monrad P, Renaud DL. Typical Clinical Findings Should Prompt Investigation for Juvenile Huntington Disease. Pediatr Neurol. 2013;48(4):333-4. doi:10.1016/j.pediatrneurol.2012.12.023

9. Letort D, Gonzalez-Alegre P. Huntington's disease in children. In: Dulac O, Lassonde M, Sarnat HB, editors. Handbook of clinical neurology. Edinburgh: Elsevier; 2013. p. 1913-7. (Pediatric Neurology Part III). doi:10.1016/B978-0-444-59565-2.00061-7

10. Ribaï P, Nguyen K, Hahn-Barma V, Gourfinkel-An I, Vidailhet M, Legout A et al. Psychiatric and cognitive difficulties as indicators of juvenile Huntington disease onset in 29 patients. Arch Neurol. 2007;64(6):813-9. doi:10.1001/archneur.64.6.813

11. Siesling S, Vegter-van der Vlis M, Roos RA. Juvenile Huntington disease in the Netherlands. Pediatr Neurol. 1997;717(1):37-43. doi:10.1016/S0887-8994(97)00069-6

12. Squitieri F, Pustorino G, Cannella M, Toscano A, Maglione V, Morgante $L$ et al. Highly disabling cerebellar presentation in Huntington disease. Eur J Neurol. 2003;10(4):443-4. doi:10.1046/j.1468-1331.2003.00601.x

13. Barker RA, Squitieri F. The clinical phenotype of juvenile Huntington's disease. In: Quarrell OWJ, Brewer HM, Squitieri F, Barker RA, Nance MA, Landwehrmeyer BG, edtors. Juvenile Huntington's disease and other trinucleotide repeat disorders. New York: Oxford University Press; 2009.

14. Lehman RK, Nance M. Family history in juvenile Huntington Disease Do the signs point to "yes" or "very doubtful"? Neurology. 2013;80(11):976-7. doi:10.1212/WNL.0b013e31828728ce

15. ACMG/ASHG statement. Laboratory guidelines for Huntington disease genetic testing. Am J Hum Genet. 1998;62(5):1243-7.

16. Toufexis M, Gieron-Korthals M. Early testing for Huntington disease in children: pros and cons. J Child Neurol. 2010;25(4):482-4. doi:10.1177/0883073809343315

17. Gonzalez-Alegre P, Afifi AK. Clinical characteristics of childhood-onset (juvenile) Huntington disease: report of 12 patients and review of the literature.J Child Neurol. 2006;21(3):223-9. doi:10.2310/7010.2006.00055

18. Gatto E, Parisi V, Persi G, Converso DP, Etcheverry JL, Varela $\checkmark$ et al. Clinical and genetic characteristics in patients with Huntington's disease from Argentina. Parkinsonism Relat Disord. 2012;18(2):166-9. doi:10.1016/j.parkreldis.2011.09.011

19. Loy CT, McCusker EA. Is a motor criterion essential for the diagnosis of clinical Huntington disease? PLoSCurr. 2013;5. pii:ecurrents.hd.f4c66bd51e8db11f55e1701af937a 419 . doi:10.1371/currents.hd.f4c66bd51e8db11f55e1701af937a419

20. Ross CA, Aylward EH, Wild EJ, Langbehn DR, Long JD, Warner $\mathrm{JH}$, et al. Huntington disease; natural history, biomarkers and prospects fortherapeutics. Nat Rev Neurol. 2014;10(4):204-16. doi:10.1038/nrneurol.2014.24

21. Reilmann R, Leavitt BR, Ross CA. Diagnostic criteria for Huntington's disease based on natural history. Mov Disord. 2014;29(11):1335-41. doi:10.1002/mds.26011

22. Reyes Molón L, YáñezSáez RM, López-IborAlcocer MI. Juvenile Huntington's disease: a case report and literature revie]. Actas Esp Psiquiatr. 2010;38(5):285-94.

23. The U.S.-Venezuela Collaborative Research Project, Wexler NS. Venezuelan kindreds reveal that genetic and environmental factors modulate Huntington's disease age of onset. Proc Natl Acad Sci USA. 2004;101(10):3498-503. doi:10.1073/pnas.0308679101

24. Nopoulos PC, Aylward EH, Ross CA, Mills JA, Langbehn DR, Johnson HJ et al. PREDICT-HD Investigators and Coordinators of the Huntington Study Group. Smaller intracranial volume in prodromal Huntington's disease; evidence for abnormal neurodevelopment. Brain. 2011;134(1):137-42. doi:10.1093/brain/awq280

25. Lee JK, Mathews K, Schlaggar B, Perlmutter J, Paulsen JS, Epping E, et al. Measures of growth in children at risk for Huntington disease. Neurology. 2012;79(7):668-74. doi:10.1212/WNL.0b013e3182648b65

26. Robertson L; Santini H, O'Donovan KL,Squitieri F, Barker RA, Rakowicz M et al. Current pharmacological management in juvenile Huntington's disease. PloSCurr. 2012;4;RN1304. doi:10.1371/currents.RRN1304

27. Papapetropoulos S, Lopez-Alberola R, Baumbach L, Russell A, Gonzalez MA, Bowen BC et al. Case of maternally transmitted juvenile Huntington's disease with a very large trinucleotide repeat. Mov Disord. 2005;20(1):1380-3. doi:10.1002/mds.20557 